\section{Obituary Peter J Morgane}

Neuropsychophamacology (201 I) 36, 2785; doi: I0.1038/npp.20 I I. 150

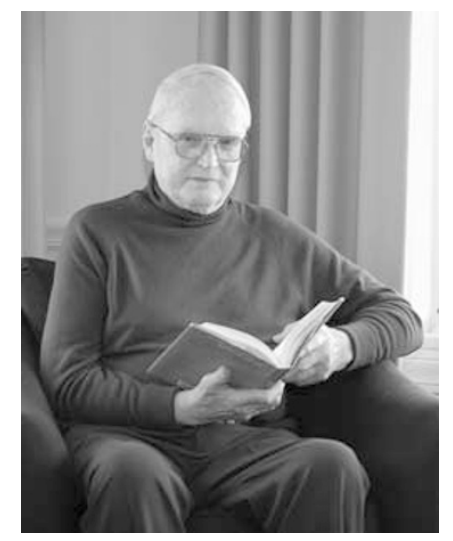

Dr Peter J Morgane, Neuroscientist and Neuropharmacologist, died on Monday, 27 September 2010, at Southern Maine Medical Center, following a short illness. Dr Morgane has been a resident of Kennebunkport since 1980. He was predeceased by his wife, Cécile Murette Morgane, who died in 2001. He was born in Atlanta, Georgia, and spent numerous early years in New Orleans. He received his Bachelor's Degree from Tulane University in New Orleans. Dr Morgane served as a page in the United States Senate in 1943 and 1944. He served in the US Army in 1947-1948 at Fort Hood and Camp Moxey, Texas.

He did his graduate studies at Northwestern University Medical School in Chicago, receiving both his Masters degree and PhD. in Neurophysiology. His work at Northwestern focused on feeding behavior, and he was particularly intrigued with the Klüver-Bucy Syndrome. His interest in feeding behavior and the effects of nutrition on brain development were key aspects of his research throughout his career.

He did postgraduate work at the University of Oregon in Portland, Oregon, and the Brain Research Institute in Mexico City, working at the latter with the famous sleep researcher, Dr Raul Hernandez Peon. He continued his interest in sleep research throughout his career, publishing more than 40 research papers in the field. His interest in sleep research led to a deeper interest in serotonin and the limbic system, which he worked on until his death.

He then did research with Dr John Lilly on aspects of whale brain anatomy, carrying out most of these studies with Dr Paul Yakovlev at the Department of Neuropathology, Harvard Medical School, Boston, MA. Dr Morgane's studies on whale brains were published in several monographs and some 40 scientific papers, from 1962 to 1998. These studies form the definitive works on whale brain, both large and small (dolphins, porpoises and whales).

Dr Morgane moved to Worcester, MA, in 1968 as head of the sleep research laboratories at the Worcester Foundation for Experimental Biology in Shrewsbury, MA. There he was the director of the Training Program for Neurobiology from 1970 to 1975 . He also began work on a Program Project dealing with effects of prenatal protein malnutrition on the developing brain, which he worked on until the time of his passing. That program moved to Boston University Medical School in 1987 under the leadership of Dr Janina Galler and was funded by the National Institute of Child Health and Human Development. The program moved to Judge Baker Children's Center at Harvard Medical School in 2007, with funding from the National Institute of Mental Health. At Boston University, he was a Professor in the Department of Psychiatry. At the same time, he was Professor of Pharmacology at the University of New England in Biddeford, Maine.

In his scientific career, Dr Morgane published over 230 scientific papers and edited the four-volume Handbook of the Hypothalamus. He was a member of 16 scientific societies. He served for 11 years on grant reviews at the National Science Foundation and at the National Institutes of Health for over 35 years. At the University of New England, Dr Morgane worked with Dr David Mokler on serotonin and the limbic system, and they edited a volume of the Neuroscience and Biobehavioral Reviews entitled 'The Limbic Brain: Continuing Resolution'. He became Professor Emeritus at UNE in June 2010.

In recent years, Dr Morgane has given considerable support to the University of New England. He has funded the Cécile Morgane Research Laboratory, as well as the Peter and Cécile Morgane Hall. This has created considerable laboratory research space for the College of Osteopathic Medicine, and offices and laboratories for the College of Arts and Sciences.

Dr Morgane's principal endeavors outside of science included book collecting, antique gathering, champagne tasting and world-wide travel to over 45 countries, including Japan, India, Australia, East Africa, Israel and all of the countries of Europe. He and his wife, Cécile, who was born in France, particularly loved going to France to sample the great beauty of the country, as well as the wine and food. In recent years, he enjoyed the pleasure of good champagne and will be remembered for his champagne tasting parties. He loved animals, especially his cat Monet who was his constant companion since his wife's death. $\mathrm{He}$ contributed to the care of animals at the Animal Welfare Society in West Kennebunk. He died as a member of the Roman Catholic Church.

He is greatly missed by his friends and colleagues.

David J Mokler ${ }^{1}$

${ }^{1}$ Department of Pharmacology, University of New England, College of Osteopathic Medicine, Biddeford, ME, USA E-mail:DMokler@une.edu

Photo by Edward Bilsky 